\title{
Implementation of al-Ma'un Theology: The Movement of Muhammadiyah Educated Groups in Poverty Alleviation in Bulutellue Village, Sinjai Regency
}

\author{
Abdul Rahman, Muhammad Syukur, Jumadi \\ Universitas Negeri Makassar, South Sulawesi, Indonesia \\ abdul.rabman8304@unm.ac.id,m.syukur@unm.ac.id,jumadi@unm.ac.id
}

\begin{abstract}
In the concept of Islamic community development, welfare is an ideal condition for any social life. Efforts to create prosperity in Bulutellue Village also received attention from the Muhammadiyah education group. They invite the community, especially those from the rich to provide sustainable assistance to groups of the poor and orphans as a form of mainstreaming al-Ma'un theology. This study aims to describe the implementation of al-Ma'un theology in alleviating poverty in Bulutellue Village, Sinjai Regency. This study employed a qualitative method. The data were collected through observation and interviews. The results indicate that al-Ma'un theology was introduced by the educated group of Muhammadiyah Higher Education to the community of Bulutellue Village. This doctrine is accepted and implemented by the community in this village even though they are not registered as official members of the Muhammadiyah organization as an effort to make their income a way of gaining happiness and getting blessings from Allah SWT towards mutual benefit.
\end{abstract}

Keywords: mainstreaming, happiness, social care

Permalink/DOI: .https://doi.org/10.18326/infsl3.v15i1.25-50 


\section{Introduction}

Al-Ma'un theology is the basis for the establishment and development of Muhammadiyah (Burhani, 2016). The theology was introduced by Ahmad Dahlan which is based on the al-Qur'an, Surah al-Ma'un which consists of seven verses, translated into the spirit of work, namely the services in the fields of health, education, and social services (Sumarno, 2017). Emphasis on the spirit of work cannot be separated from the early establishment of Muhammadiyah as a response to the social conditions of the community which was hit by educational backwardness, poverty, and the waning spirit of cooperation (Suryana, 2009). Ahmad Dahlan as the founder of Muhammadiyah emphasized to his students to appreciate the content of Surah al-Ma'un by balancing worship and social deeds (Mustapa, 2017).

Muhammadiyah as a social organization is always wise for the benefit of the community (Purba and Ponirin, 2013). Muhammadiyah's determination to create community welfare is proven by establishing educational institutions, health institutions, and social institutions. Utilizing those institutions, Muhammadiyah tries to build a more advanced and educated social and community education structure. Islamic teachings are presented not just as a personal and static religion but are presented as a dynamic religion and have concern for all aspects of people's lives (Widodo \& Yusuf, 2019).

Religion, which contains a system of values, norms, and guidelines, a system from God to mankind, has a very big role in realizing the progress, prosperity, and civilization of a nation (Asim et al., 2020). As a socio-religious and community organization, Muhammadiyah has played a very active role in nurturing and empowering the community since its establishment through education, preaching, and social activities. This cannot be separated from the existence of Muhammadiyah which is supported by scholars, and educated people. They have a very big role in spreading the vision and mission of Muhammadiyah in various parts of Indonesia, including the rural areas.

Muhammadiyah is an Islamic movement that aims to carry 
out preaching or da'wab in inviting goodness and truth as well as staying away from all forms of evil in order to uphold Islam and create an Islamic society in accordance with the al-Qur'an and Hadith. Muhammadiyah has an insight that Islam is a religion that regulates all aspects of human life which consists of aqidah, worship, morality, and social relations that must be carried out by Muslims in a comprehensive manner, both individually and collectively. By implementing these teachings in daily life, Muhammadiyah believes that Islam can be proven as a religion that brings blessings to the entire universe and its contents. Muhammadiyah as an effort to overcome poverty is one of the da'wah activities oriented to tathwir or community empowerment (Muslim, 2016).

As an effort to realize Muhammadiyah's aspirations and struggles in society, improving the world of education is one of the main considerations (Qodir, 2004). Muhammadiyah's attention to the education sector is motivated by the desire to break the chain of poverty, ignorance, and backwardness that afflicts Muslims (Hamdan, 2009). To advance education and create intelligence for Muslims, Muhammadiyah established educational institutions ranging from Kindergarten to Higher Education levels. Currently, the tertiary institutions that are fostered by Muhammadiyah are not only in the provincial capital but are already present at the district/municipal level. The universities fostered by Muhammadiyah (PTM), namely the Muhammadiyah University of Makassar and the Muhammadiyah Islamic Institute of Sinjai, have opened opportunities for high school graduates/equivalent who come from the Bulutellue Village to study at the higher education level.

Students and alumni of PTM can be categorized as an enlightened (intellectual) group that can provide changes in the mindset and behavior of the community in Bulutellue Village. In the history of South Sulawesi, intellectual circles have played a major role in encouraging and creating new orders in people's lives (Najamuddin, 2015). PTM alumni who have bachelor's degrees and status of teachers are very capable of carrying out a da'wah movement to provide awareness to all Muslims in Bulutellue Village. The presence of a teacher in the village community still has a respectable position and can be a role model for the community 
(Saat, 2014). Respect for teachers or educated groups is a custom inherited from the kingdom era by the people of Bulutellue Village. Historical facts show that the Islamization process in Sinjai cannot be separated from the role of intellectuals. Thus, this area is known as the earth of panrita kitta, people who have expertise in the sciences of the al-Qur'an (Hasaruddin et al., 2018).

The presence of educated groups in Bulutellue Village is a process of social mobility produced by PTM for its students. In general, the educated group from PTM has a family background categorized as middle class, such as working as farmers. Due to this social background, PTM educated groups have the ability to socialize and adapt to the community to convey Islamic da'wah. They understand that the people of Bulutellue Village are very firm in adhering to and carrying out customs. Therefore, culture is introduced to the community as a way or method of introducing a certain religious concept.

As an effort to carry out the mission of da'wah based on culture, PTM educated groups always show the struggle of Islam which is friendly, polite, full of peace, and joyful. They try to preach, no longer with a one-way approach, but by building dialogue and establishing harmony with society without being limited by space and time. Da'wah or preaching activities are not only centered in mosques but can be carried out in spaces that are occupied by many people in utilizing free time to rest from economic activities, for example in the house or at the substation. The use of space outside the mosque for preaching shows that the PTM educated places itself not to patronize the community, but to learn with the community.

As a formulation of Muhammadiyah practice theology presented to the community, there are four basic groups that are the main focus in reviving the spirit of religion in the community:(1) the basis of faith is faith in God, angels, scriptures, prophets, doomsday, and both good and bad destiny; (2) the basis of social devotion is by donating some of the property owned to provide assistance to close families in distress, orphans, the poor, and people in debt; (3) the basis of ritual and worship is to maintain and strengthen the 
inner commitment as Muslims by seriously upholding the five daily prayers, and sincerely paying zakat; (4) basic personality qualities are being steadfast in keeping promises and being steadfast in facing difficult conditions.

The PTM educated group understands the reality of the Bulutellue Village community, where most of their economic activities are based on the agricultural sector (agrarian society). In an agrarian society, there are three groups of people, namely landowners, smallholders, and farm laborers who usually come from landless people. Farmworkers are vulnerable to poverty, in the sense that when the dry season arrives, there is no rice processing activity. Therefore, they do not have the income to meet the needs of their families. The poverty faced by agricultural labor groups has been explained by Moeljarto Tjokrowinoto that the position of the poor around the poverty line is vulnerable to various ecological fluctuations such as pest attacks and a long dry season (Tjokrowinoto, 2012). These conditions were then used as material for discussion in the Friday sermon when PTM educated group appeared as a preacher. They try to open people's minds and feelings by reaffirming Surah al-Ma'un which describes how futile people who pray but ignore the poor and orphans. Surah alMa'un recommends that Muslims pay attention to people who are backward, oppressed, and still in poverty.

In every da'wah, PTM educated groups emphasize the importance of the position of the poor in social life. Community life in a village will receive the blessings and mercy of Allah if it is supported by four groups, namely: the usefulness and blessings of knowledge from a scholar, justice and wisdom from the government, generosity of the rich, and the prayers of the poor. This indicates that groups of poor people must get attention to make their lives sustainable and to maintain their faith as religious people. Thus, the presence of the PTM educated group in Bulutellue Village also affirms that Muhammadiyah as a socio-religious organization has a mission to spread Islamic teachings that uphold equality in various sectors of life. This indicates that religious organizations have an important role in making it happen (Nasir et al., 2019) 


\section{Methods}

This study employed a qualitative descriptive method as an effort to focus attention on events that occur in the community through data collection, data presentation, data explanation, and data analysis. Primary data were obtained by collecting information from an educated group of PTM, entrepreneurs, and large land farmers as initiators and implementers of al-Ma'un theology. To strengthen the information from the interviews, observation of the economic activities carried out by the target group was also carried out.

Data analysis was carried out by giving meaning to people's behavior related to their understanding of al-Ma'un theology. The meaning that is built on the condition of the relationship and experience of the community is then presented as research data in the form of a descriptive narrative. Data were presented by making connections between data. Thus, the analyzed data were really presented in an inseparable narrative based on the informant's perspective. Meanwhile, in drawing conclusions, the data were patterned, focused, and arranged systematically based on the confirmation results of the informants on the research theme.

\section{Results and Discussion}

\section{Farmers' Understanding of al-Ma'un Theology}

At the $106^{\text {th }}$ Muhammadiyah anniversary event under the theme of Ta'awun for the country, Haedar Nashir emphasized that Muhammadiyan continues to promote the message of Islamic calm in an attitude of helping for the shade of the nation (Nashir, 2018). This affirmation is a response to economic inequality in the form of uncontrolled poverty and unemployment as well as the failure of the concept of a welfare state in realizing justice and prosperity for society (Elviandari et al., 2018). As is common in Muslim-majority countries, the task of alleviating poverty is not only borne by the state or government, but it is also necessary for the general public to participate in providing social security for underprivileged groups (Gamon \& Tagoranao, 2018). This message is certainly a spirit for all Muhammadiyah members, including the PTM educated group in Bulutellue Village to continue to move towards realizing community welfare.

The preaching of PTM educated groups which contains the 
importance of working together and advancing together in alleviating poverty and supporting orphans continues to be encouraged by conveying the main essence of surah al-Ma'un. The efforts of the PTM educated group in providing inspiration to the community to implement the al-Ma'un theology received a warm welcome from the public. The theological doctrine of al-Ma'un, which is based on the importance of praying, is required to be accompanied by a generous attitude toward those who are less fortunate, especially towards orphans and the needy. The PTMeducate group emphasized that Islami which is based on the al-Qur'an and Hadith strongly encourages humans to earn a living in order to create common prosperity while avoiding greed, waste, and accumulation of wealth (Nabi, 2013).

The understanding of the Bulutellue Village community about al-Ma'un theology was then used as a spirit in strengthening the economic sector. Islam which they understand on the basis of al-Ma'un theology evokes a spirit of earning a living. Therefore, the results can be shared with the poor to obtain an essential degree of piety in ritual worship and in social relations with others. A comprehensive understanding of al-Ma'un theology leads to strong kinship ties and solidarity between communities even though they differ in genealogical ties. This reflects that the people in this village have succeeded in creating a community structure with a social dimension, namely a society that upholds the values of human solidarity and strengthens an egalitarian culture (Bachtiar, 2018).

The theology of al-Ma'un is lived by the community further strengthens the position of Bulutellue Village as a makkiade (traditional) and fagama (religious) village. The meeting between customs and religion is reflected in the attitude of the people of Bulutellue Village who are masega (friendly), makasse assisompungenna (close family ties), and matike ri sirina (maintain their dignity and self-worth). The presence of al-Ma'un theology in the community has given individuals freedom in trying to earn a living and social responsibility of society while still paying attention to the welfare of family members. Thus, the pattern of orientation in earning a living for the people of Bulutellue Village aims to obtain blessings from Allah by providing assistance to groups who are 
economically disadvantaged and providing material sufficiency for family members (Hadi \& Baihaqi, 2020). Furthermore, the spirit of surah al-Ma'un has strengthened individual and group ties based on feelings of the same fate and cooperation fosters an attitude of optimism and competes in working and doing good to create a balance between material and spiritual matters. Thus Islam and customs have collaborated in society in realizing collective bonds as social capital that they can implement in their daily lives (Oktafia \& Mawardi, 2017).

The solidarity that has been built up among the people of Bulutellue Village is getting stronger because it is inspired by alMa'un theology. The roots of solidarity based on mutual cooperation are oriented towards activities of mutual assistance in overcoming life's hardships. The long-standing solidarity is manifested in various community activities such as building houses, repairing public facilities, holding village events or parties, and caring for one another when disasters occur, such as fires and deaths. Al-Ma'un theology has become part of the moral values and wisdom of the Bulutellue Village community which emphasizes the importance of solidarity and togetherness in building hopes and trust among community members. The theological strength developed by PTM educated groups in society raises the understanding that religion is not just a doctrine of obedience to God to achieve salvation in the hereafter, but religion needs to be implemented in overcoming the economic difficulties experienced by the poor and orphans. Religion has played a role in realizing social change in the sense of being able to change fatalistic societal behavior into a society that is more optimistic, resilient, and has a high work ethic in earning a living (Sirait, 2016).

Surah al-Ma'un is the teachings for humans to communicate with Allah through ritual worship, as well as a warning that humans strengthen relationships and social care for others through various charitable activities. Understanding of social relationships among humans is practiced through social communication which is created based on a sense of concern, high concern, and a great sense of responsibility to fellow humans by providing compensation to orphans and carrying out empowerment activities for the poor 
with the intention that they are able to live independently and prosperously. In terms of giving compensation to orphans, it is usually given directly in the form of clothes, school supplies, money, and food. The empowerment activities for the poor are carried out by inviting them to work by providing facilities in the form of agricultural land and business capital.

The people of Bulutellue Village, who generally earn a living in agriculture, realize that land as the main resource in their economic search has a very important role to play. However, not all members of the community in this village have large enough land to make a living, and some even have no land at all. Al-Ma'un theology has raised collective awareness for them, especially among landowners who are large enough to share land resources in overcoming unequal economic conditions, especially in terms of equitable food distribution. This shows that the people in this village have a shared commitment to creating public welfare. The distribution of economic resources to the underprivileged groups shows that there is a partiality for the problem of poverty as a responsibility in promoting community welfare by utilizing agricultural resources as practiced by the farming community in Malaysia (Ab Rahman et al., 2019). Public concern for the phenomenon of poverty has been in line with the PTM educated group program in poverty alleviation in rural areas in reaching progressive Muslims and Indonesian people (Bachtiar, 2020).

The presence of a PTM educated group in the life of the Bulutellue Village community has led to a change in the orientation of attitudes and thoughts since they are a society that is open and willing to accept new ideas that can strengthen the social order (Mustika \& Dastina, 2020). Villagers and village officials who initially did not know Muhammadiyah, after witnessing their persistence and patience in nurturing and fostering residents to advance village life, expressed admiration. Religious doctrine, especially, al-Ma'un theology really inspires people in carrying out religious activities and expressions. The people of Bulutellue Village then have an understanding of al-Ma'un theology which is associated with the values of local wisdom that they have inherited from generation to generation, including Pesse, Barakka, Massama, and Sugi harang 


\section{parang-sugi pappideceng}

Pesse: empathy on the basis of humanity

The village in the dimension of power politics is the smallest government unit, the smallest decision-making unit, where every decision made in the village will refer more to humans as individuals (Sumodiningrat and Wulandari, 2016). The village is a marker of local wisdom and indigenous knowledge, amidst instrumental rationality and scientific knowledge. The village as a gemeinschaft is characterized by mechanical solidarity among residents, face-toface relations in interactions, the application of customary norms and sanctions, and the economy inherit in culture and power politics. Village community social ties are based on networks of kinship, neighbors, and friendship (Salman, 2012). The strength of community ties in Bulutellue Village is based on a value system known as pesse.

Pesse is a philosophical value that can be interpreted as a sense of togetherness, sympathy, and empathy that underlies the life together (Musnur, 2018) of the people in Bulutellue Village. Togetherness is evidenced by spontaneous actions and is based on selfless sincerity to provide help to neighbors or relatives who are in distress. The community moves to provide help without being asked and only in the form of notification based on information that is so fast spreading in the village environment.

Pesse associated with al-Ma'un theology is interpreted as togetherness and kinship. Togetherness coupled with a work ethic will free a group of people from economic difficulties. The creation of an atmosphere of kinship and togetherness among community members must be able to transcend class boundaries or socioeconomic layers. Social class in the Bulutellue Village community is a social reality but in the social order of the community. This is not known, but rather a feeling of closeness between communities which is prioritized to strengthen kinship ties.

The Islamic building related to pesse is brotherhood or ukhuwah. Islam establishes the concept of brotherhood as a priority in realizing the ideal community building (Lubis, 2020). The teachings of brotherhood in Islam have a different character 
from the concept of brotherhood which is linked by genealogical ties. Brotherhood in Islam is built on the basis of the principle of monotheism, in the sense that brotherhood is built on a feeling of the same fate and agreement in an equal position and is not differentiated on the basis of property ownership, position, and social position in society. The care that is created in the community of Bulutellue Village for the suffering experienced by others is built on the basis of brotherhood that expects for the common good. Pesse is an organizer of solidarity, collectivity, and social cohesion, as well as the glorification of human values by providing assistance to fellow humans who are hit by distress (Badewi, 2019).

The persistence of the Bulutellue Village community in upholding the pesse value system is also interpreted as an effort to realize economic democracy and social justice. The implementation of economic democracy and the realization of social justice are not solely the responsibility of village government officials and religious officials but need support and practice from the general public. They understand that a society can develop and be free from various difficulties if it is supported by internal strength in the form of togetherness. Pesse as part of an attitude of religiosity is the main capital in strengthening the instinct to live well neighbors, the willingness to live side by side in a friendly manner which is reflected in mutual cooperation activities, social solidarity, and tolerance that reflects coexistence without sharpening social position or status in society.

\section{Barakka: Hope for God's Favor}

Human beings living life on this earth are always struggling to achieve happiness. When human beings have been able to meet their needs, both material and spiritual needs, happiness will be achieved. To obtain and meet the needs of clothing, food, and board, humans are required to work hard to earn a living. In the teachings of Islam, working for a living is an obligation for every Muslim. According to Yusuf Qardawi, work is all the maximum efforts made by humans, either through body movements or thoughts to earn income done individually or collectively/collaboratively (Walian, 2012). In the context of Indonesian culture, work is the role of individuals in the cultural process of obtaining a source of livelihood both in the form 
of goods and wages/rewards in the form of money (Kartodirdjo, 1994). In Islamic teachings, work is an activity of earning a living based on personality attitudes that give birth to a deep belief in gaining the glory of life, showing human social responsibility, as well as a way to obtain righteous deeds and the pleasure of Allah SWT (Sugiyanto et al., 2020).

The people of Bulutellue Village understand that working for a living is a form of devotion to Allah SWT. The purpose of working for them is to be able to meet the needs of family life. The assets they get are not only intended for the internal benefit of family members, but are also prepared for social purposes such as donations for the construction of houses of worship, public facilities, and supporting the poor and orphans. Income earned and utilized for the benefit of the household is a way to obtain happiness, while property for social interest is an effort to achieve the blessings of Allah SWT. Efforts to obtain the approval of Allah SWT on the property owned are done by setting aside part for the benefit of orphans and the poor.

\section{Massama: Distribution of income}

On the basis of the spirit of al-Ma'un theology instilled by an educated group from PTM, the people of Bulutellue Village understand that basically property is indeed support for human life. Therefore, the role of property in human life cannot be doubted. With the assets they have, they can meet the necessities of life for their families. They can also provide help to other people who are hit by economic difficulties. An understanding of al-Ma'un theology has become a spirit to work hard to earn a living based on the provisions of the Islamic religion as well as to make their assets useful for the development of Islam and can be distributed to people who are entitled.

In order for the assets owned to be massama (spread and enjoyed by others), the assets have other people's rights which must be given based on the provisions. The expended assets will not cause a decrease in wealth, let alone fall into the brink of bankruptcy and poverty. The philosophy of massama as one of the meanings of al-Ma'un theology will distance itself from selfish 
or anti-social attitudes, which might make other people victims and cause an imbalance in the order in social life. The al-Ma'un theology is used as a guideline that in order to obtain property that can benefit the family and others (massama), it takes a lot of effort while still prioritizing moral values to get blessings. This principle is in accordance with the Bugis philosophy: resofa temmangingi malomo naletei fammase Dewata SewwaE (only with hard work that does not know despair, will lead humans to obtain blessings from God).

The philosophy of massama which is understood by the people of Bulutellue Village is the antithesis of the conventional economic system which places humans as economic animals with the aim of achieving maximum benefits without paying attention to the aspects of humanity (Baidan and Aziz, 2020). Seen from an Islamic economic perspective, massama is identical to the principle of social justice, namely the responsibility of every economic actor to maintain a balance in community life by creating a society that is fulfilled all the needs for clothing, food, and shelter. Thus, there is no social inequality between the rich and the poor. Massama as an effort to distribute income by using a spiritual-based moral economic approach is a step in maintaining equality and reducing the level of inequality between the poor and the rich (Hamid et al., 2019).

Sugi Harang Parang, Sugi Pappideceng: Using Assets in Getting Rewards

In the life of the people of Bulutellue Village, the nuances of a fatalistic attitude remain. It is still embedded in the minds of the people that being rich is a disaster. Richness leads people to issues that are contrary to religious orders to live in asceticism. Being rich makes humans always think about world affairs and neglect the affairs of the hereafter. The more property one has, the greater will be the accountability in the resurrection day. Such an attitude to life is exacerbated by the lack or even no inheritance from the parents, even though the sustainability of life must be supported by material as a basis for carrying out a livelihood effort.

The presence of a PTM educated group began to shift the 
fatalistic paradigm. The passion to be rich must be encouraged. The drive to be rich was accompanied by the urge to carry out the obligation of worship as a Muslim. In the teachings of Islam, it is instructed to look for sustenance, as if one would live another thousand years. However, the assets that are owned are entrusted by Allah, wherein these assets there are rights of the poor and orphans that must be distributed. The people of Bulutellue Village who are in the category of rich people believe that everything belongs only to Allah. This belief makes them as much as possible to stay away from arrogant and takabur attitudes, but efforts are made to use these assets as a means to do more good deeds and get merit (Hasbulah \& Daud, 2015).

For the rich, their assets are interpreted as a means of doing good. They run trade and agricultural businesses to make a profit and increase their wealth. The businesses they run involved many people, in the sense that the labor they use comes from low economic status. Thus, they are always close and build together with other community groups. Therefore, they as much wealth as possible in ways that are good and lawful and try continuously to develop businesses on a larger scale. Thus, more and more people can be free from the shackles of economic difficulties.

\section{The Practice of al-Ma'un Theology}

The poverty circle that surrounds part of the community in Bulutellue Village is realized by the village government and the PTM educated group. This cannot be eliminated progressively, but it needs efforts to slowly liberate those exposed to poverty. The rich groups who have understood al-Ma'un theology do not remain silent and stand by their hands to see those who are in a circle of poverty. The formulation of the theology of al-Ma'un is not limited to strengthening the dimensions of individual piety as a form of personal obedience to Allah, but is also moved into a working theology that reflects the construction of religious belief that cares for the poor, and is socially oriented. Al-Ma'un theology brings out a sense of togetherness, roots and identity, emotional support, and a sense of security in a relationship that feels very close and deep. The very high emotional bonds of a very close relationship can lead to the idea of a common identity as Muslims, of direct participation in each other's inner 
space, and thus bring the idea that is widespread in society that the rich and the poor are closely related and familiar easily empathize with each other. The desire to help and ease the burdens of others as part of the teachings of Islam is basically positive as a basic value for its adherents. Awareness of the importance of helping each other in social life has presented religion as a functional structural force that encourages social balance. Poverty alleviation based on alMa'un theology can be categorized as social philanthropy, which is the spirit of creating prosperity by dividing property and providing employment for people who experience economic backwardness (Bahjatulloh, 2016). The concept of al-Ma'un theology which has been embedded in the understanding of the rich groups is then implemented into various forms of action to reduce the burden on the group of the poor. It can be seen in the following description.

\section{Provision of employment through livestock business}

One of the businesses in Bulutellue Village outside the agricultural sector is cattle farming. The cattle breeding business in Bulutellue Village is still stable due to the availability of natural food. This is possible because in this village there is still land that can be used as grazing land. There is also plantation land that is used to grow elephant grass as food. The availability of natural feed can minimize maintenance costs.

The cattle breeding business is one way to help the poor in overcoming economic hardship. The owners of capital or the rick buy young bulls and then hand them over to the poor to be raised. The maintenance of the cattle is not too difficult because the land and feed have been provided by the owner of the capital. What needs to be considered is the schedule of feeding and drinking to make the cattle experience rapid growth. After being kept for about 6 months, the cattle are then sold to cattle traders. The profit obtained is immediately divided by the owner of the capital and the person who maintains it.

Another business that is still related to poverty alleviation in this village is broiler chicken farming. This business has great potential because the demand for chicken meat has increased, especially to meet the demands of food stall entrepreneurs in the 
center of Sinjai City, including requests from villagers who want to hold a celebration or party. Broiler chicken farm activities are carried out independently, as well as the profits and losses are borne by themselves. As an effort by the owners of capital to ease the burden on the poor, this livestock business is managed by involving two workers to keep the pen clean and feed according to a predetermined schedule. After being raised for about 4-5 weeks, the chickens are ready to be marketed, and $15 \%$ of the sales proceeds are the rights of the caretakers.

\section{Provision of Business Capital}

In the Islamic economic system, it is known as the term distribution. One of the distributions recommended in Islam is the provision of capital to groups that are vulnerable to poverty to be able to open a business (Aflaha, 2019). Providing business capital is one way to alleviate poverty (Suryanto, 2018) by the rick against the poor in Bulutellue Village. One of the groups that are vulnerable to poverty in Bulutellue Village is a woman who has the status of a widow. Poverty began to hit when the husband who had been the head of the household as well as the main breadwinner died. As a consequence, the wife who is left behind has to assume various roles, namely as the head of the household, as the breadwinner, as well as the mother who has to educate and raise children. In the midst of the difficult conditions, windows are still trying to carry out very decisive roles for household survival, namely: maintaining viability, working outside the home, and earning income.

The economic hardship that hit the window's household received serious attention from a construction service entrepreneur (CV. Lubis) in Bulutellue Village. After understanding the concept of al-Ma'un theology conveyed by the PTM educated group in the Friday sermon pulpit, the entrepreneur took the initiative and consulted the village government to provide assistance in the form of business capital for the widow. The entrepreneur's motive to provide capital assistance to the widow is an expression of gratitude for the success of the business he has been engaged in for about 3 years, as well as proof of his determination to provide opportunities for the widow to be able to get the same welfare as the family around him. Furthermore, capital assistance is expected 
to empower the household economy of widows. Thus, their lives do not need to depend on other people and at the same time protect them from the negative stigma that is sometimes perceived by the community towards widows. After obtaining approval from the Head of Bulutellue Village and a survey of the economic conditions of the beneficiary's target widows, the entrepreneur gave the funds. The criteria for widows who are entitled to receive this assistance are that they have owned a business, are still productive at work and have dependents who are still small and go to school. The criteria for widows who are entitled to receive this assistance are that they have owned a business, are still productive at work and have children who are still young and go to school. Each person receives IDR 3,000,000 in assistance and there is no obligation to return it. The types of businesses that receive assistance are food products sold in traditional markets. Each beneficiary has different types of products, namely cassava tape, apem and steamed cake, donuts and buns, coffee shop business, and grocery store business.

After being evaluated by the providers of capital, in the last one after they received additional capital assistance, the household economy of widowed women can run stable, characterized by the ability to provide balanced nutritious meals 3 times a day and be able to pay for school suppliers and transportation for their children. Based on the acknowledgment of those who received assistance, the benefits ranged from IDR 500,000 to IDR 750,000 per month. These benefits for them are more than sufficient if measured based on the needs of the Bulutellue Village community.

\section{The distribution of agricultural land using the profit-sharing (teseng) system}

As an agricultural village, Bulutellue puts land in a very strategic position. The land is a production factor that is very important for the welfare of farmers. Without owning land, a farmer's life has no meaning because he and his family must live in poverty. Therefore, owning land is the desire to live faithfully for farmers in Bulutellue Village, whether they do not own land or those who own narrow land. Almost all farming communities in Bulutellue Village cultivate rice fields and gardens, even though there are farmers who do not own their own land. Farmers who do not own land, farm by 
cultivating land owned by farmers who have large land (teseng). According to George Homans, this teseng system is a form of social exchange that is still in a strong position in rural areas, where the parties involved are mutually beneficial (Prasetyo et al., 2013).

The teseng system is a way for farmers with large areas to provide assistance to farmers who do not own land in order to survive and provide a living for their family members to avoid poverty traps. The implementation of the teseng in Bulutellue Village is an agreement between the landowners and the tenants, which has resulted in various models. A farmer who has wide land gives his land to other people to work on it indefinitely, as long as the land can be cared for properly. Cultivators are given the opportunity to cultivate the land for three consecutive years without profit sharing and are only obliged to pay taxes (rent). Entering the fourth year, the profit-sharing system is implemented. If the field produces 10 sacks of grain, then 4 sacks are for landowners, 4 sacks are for cultivators, while the 2 sacks are taken by the party who provides fertilizer. If the landowner provides fertilizers, the 2 sacks will be his share and vice versa.

Apart from being processed for planting rice, paddy fields adjacent to the watershed are also used to plant secondary crops (corn and peanuts), vegetables in the form of eggplant, chilies, long beans, and cucumbers when the dry season arrives. However, landowners do not demand a production sharing system for agricultural businesses that are carried out in the dry season. Farmers who own land understand that their business really requires hard work from smallholders in order to get the maximum results. However, smallholders also feel reluctant if they do not share with landowners. In order for smallholders to be free from any hard feeling, they usually bring some of the agricultural produce to be enjoyed or consumed by the farming families who own the land.

Some of the teseng models implemented by landowners and smallholders are not based on an open sharing system, but a location sharing system. The landowner who owns two rice fields, one location is entirely up to the tenant farmers, but the production costs and taces (rente) are borne by the tenant farmers. However, 
smallholders have an obligation to cultivate rice fields from the landowner at one other location, where the results of the rice fields are the right of the landowner, and production costs and taxes are the obligations of the landowner.

\section{Direct Assistance}

Efforts to alleviate the economic difficulties faced by the poor are by providing direct assistance in kind and in cash. Assistance in the form of goods is usually given when a poor household is about to hold a celebration or party, such as weeding or aqiqah. This assistance generally comes from entrepreneurs and farmers with large areas of land. The entrepreneurs usually distribute aid in the form of flour, butter, cooking oil, and sugar. Meanwhile, there are farmers who have large areas of land who donate rice, coconuts, eggs, and chickens. The generous attitude carried out by entrepreneurs is a rational action in the Islamic economic system that cares deeply about the difficulties of others as well as proof that they put forward the common good rather than personal satisfaction (Mansur, 2017).

On average, cash assistance originates from entrepreneurs aimed at school children from poor families. Every time entering a new academic year or after holidays, entrepreneurs come to the children at their homes to be given cash assistance. Thus, they can be used to meet school supplies, such as clothes and notebooks or textbooks. The assistance was deliberately distributed by entrepreneurs in this village. Thus, school-age children could receive a proper education to be used in their future lives, as well as a means to improve their family's socio-economic status.

\section{Al-Ma'un Theology and Community Empowerment}

The provision of assistance by groups of the rich to groups of the poor shows that al-Ma'un theology is oriented towards increasing the level of social welfare through social and humanitarian activities in order to meet the basic needs of society in the fields of education and economy. As part of a form of social development, community empowerment is currently becoming the mainstream as a preferred approach to development as an effort to create community welfare (Soetomo, 2018). The poor groups as aid recipients view that the assistance they receive is a form of humanitarian social assistance 
pioneered by the PTMeducated group in the form of activity packages oriented towards community empowerment, especially in the fields of education and economy. Looking at the social and humanitarian activities in Bulutellue Village are community development and empowerment activities, this activity should be consulted with the village officials and community leaders as influential people in the community in advance. Consultation and blessing from the government and community leaders in Bulutellue Village were deliberately carried out by PTM educated groups to avoid suspicion. Zubaedi expressed the suspicion of groups engaged in community empowerment that commitment to the oppressed and poor, to disgrace, and to bring about social change often creates difficulties for the lives of community development activists. Activists who in their daily lives are on the side of the weak are sometimes slandered as instigators (Zubaedi, 2007).

The efforts of the PTM educated group in alleviating poverty in Bulutellue Village through da'wah or preaching by mainstreaming the concept of al-Ma'un theology have touched the hearts of the people to participate in realizing common welfare and benefit as Muslims. In Islamic teachings, the realization of welfare is not only borne by the state and government but also is the responsibility of the general public, business actors, or individuals who are classified as wealthy and financially capable. Community empowerment based on al-Ma'un theology puts the community as the dominant factor in creating prosperity in Bulutellue Village. Thus, efforts to maintain and improve welfare are a process of, by, and for society.

The theology of al-Ma'un which was promoted by the PTM educated group is categorized as a social movement, which is an action within the framework of common life. Thus, it always pays attention to problems that arise in people's lives (Mulkhan, 2000). Implementation of al-Ma'un theology which is oriented towards community empowerment using the poverty alleviation approach. This approach emerged as a response to the rural and agricultural modernization strategy which was considered unsuccessful in overcoming poverty in Bulutellue Village. This approach seeks to encourage poor rural groups, namely farm laborers, smallholders, widows, and orphans to remain productive in a sustainable manner 
in fulfilling their daily needs.

Community participation in realizing social welfare and alleviating poverty in Bulutellue Village which is based on alMa'un theology can be realized for some reasons: (1) creating an atmosphere or condition for the community to develop all its potential; (2) PTM educated groups, government, and owners the capital (rich people) as the main actor are present to strengthen the capacity and potential of the target community; (3) the target community for empowerment is given the freedom to use the assistance they receive for the sustainability of their family life. This condition proves that in Bulutellue Village a society has been created that pays attention to social balance as well as the presence of circulation of wealth to all members of the community. The spirit of al-Ma'un theology has prevented the accumulation of wealth and control of natural resources in a handful of individuals, as well as creating social responsibility from the rich to the poor.

\section{Conclusion}

To sum up, the results of this study can be concluded that al-Ma'un theology introduced by the educated group of Muhammadiyah Higher Education (Perguruan Tinggi Muhammadiyah, abbreviated as PTM) has brought changes to economic conditions among the poor and orphans. This change is marked by the emergence of siding with the rich towards the poor and orphans. This alignment is marked by the emergence of collective action from the rich to distribute part of their assets, either for direct consumption or in the form of providing business capital to the poor and orphans. The spirit of partisanship has become social capital in gluing social relations patterns based on kinship ties between all levels of society in Bulutellue Village in realizing mutual welfare. 


\section{References}

Ab Rahman, M. F., Thaidi, H. A., Baharuddin, A. S., Ab Rahman, A., \& Ab Rahim, S. F. (2019). Expansion of Agricultural Zakat Revenue in Malaysia on the Basis of the Current Maslahah. AlJami'ab: Journal of Islamic Studies, 57(1), 231-256.

Aflaha, A. N. (2019). Perspektif Islam Terhadap Distribusi Kekayaan Dalam Hubungan Juragan-Punggawa Sawi Pada Kehidupan Nelayan. Jurnal Iqtisaduna, 5(2), 124-138.

Asim, M., Zaheer, M. A., \& Roofi, Y. (2020). Constitutional Economics under an Official Thought to be Divinely Guided. Journal of Islamic Thought and Civilization, 10(1), 273-287.

Bachtiar, H. (2018). Towards a Progressive Interpretation of Ummah. Indonesian Journal of Islam and Muslim Societies, 8(1), 87116.

Bachtiar, H. (2020). Dar al-Ahd wa al-Shah dah: Muhammadiyahs Position and Thoughts on Negara Pancasila. Studia Islamika, $27(3), 485-513$.

Badewi, M. H. (2019). Nilai Siri' dan Pesse dalam Kebudayaan Bugis-Makassar, dan Relevansinya terhadap Penguatan Nilai Kebangsaan. Jurnal Sosiologi Walisongo, 3(1), 79-96.

Bahjatulloh, Q. M. (2016). Pengembangan Pemberdayaan Ekonomi Masyarakat Melalui Kegiatan Filantropi (Studi Kasus Lembaga Tazakka DIII Perbankan Syariah IAIN Salatiga). Inferensi: Jurnal Penelitian Sosial Keagamaan, 10(2), 473-494.

Baidan, N. \& E. A. (2020). Upaya Pengentasan Kemiskinan: Perspektif Ekonomi Islam Berbasis Teologi. Yogyakarta: Pustaka Pelajar.

Burhani, A. N. (2016). Muhammadiyah Berkemajuan: Pergeseran Dari Puritanisme Ke Kosmopolitanisme. Bandung: Mizan.

Elviandari, E., Farkhani, F., Dimyati, K., \& Absori, A. (2018). The Formulation of Welfare State:the Perspective of MaqàsidalSharì’ah. Indonesia n Journal of Islam and Muslim Societies, 8(1), 117-146.

Gamon, A. D., \& Tagoranao, M. S. (2018). Zakat and Poverty 
Alleviation in a Secular State: The Case of Muslim Minorities in the Philippines. Studia Islamika, 25(1), 97-133.

Hadi, N., \& Baihaqi, J. (2020). Motive of CSR Practices in Indonesia: Maqasid al-Sharia Review. QIJIS (Qudus International Journal of Islamic Studies), 8(2), 327-352.

Hamdan. (2009). Paradigma Baru Pendidikan Muhammadiyah. Yogyakarta: Arruz Media.

Hamid, A., Prasetyowati, R. A., \& Trisasmita, R. (2019). Implementasi Konsep Distribusi Pendapatan dalam Islam untuk Meningkatkan Kondisi Sosial Ekonomi Masyarakat di Provinsi Jawa Barat. INFERENSI: Jurnal Penelitian Sosial Keagamaan, 13(2), 219252.

Hasaruddin, H., Mania, S., \& Anis, M. (2018). Islamization in Sinjai in the 17Th Century: the Arrifal of Islam and Social Change. Al-Shajarah: Journal of the International Institute of Islamic Thought and Civilization (ISTAC), 23(2), 339-362.

Hasbulah, M. H., \& Daud, M. Z. (2015). Perancangan Pembahagian Harta Semasa Hidup dalam Islam: Konsep dan Kepentingannya. Global Journal Al-Thaqafah, 5(1), 119-131.

Kartodirdjo, S. (1994). Pembangunan Bangsa: Tentang Nasionalisme, Kesadaran dan Kebudayaan Nasional. Jakarta: Aditya Media.

Lubis, R. (2020). Merawat Kerukunan: Pengalaman Indonesia. Jakarta: Elex Media Komputindo.

Mansur, M. (2017). Preferensi Konsumsi Keluarga Perspektif Ekonomi Islam (Studi kasus di kelurahan Wates, Ngaliyan Kota Semarang). Inferensi: Jurnal Penelitian Sosial Keagamaan, 11(2), 409-430.

Mulkhan, A. M. (2000). Menggugat Muhammadiyah. Yogyakarta: Fajar Pustaka Baru.

Muslim, A. (2016). Pemberdayaan Ekonomi Masyarakat Miskin di Yayasan Perjuangan Wahidiyah. Inferensi: Jurnal Penelitian Sosial Keagamaan, 10(2), 335-358.

Musnur, I. (2018). Simbolisasi dan Implementasi Pacce (Solidaritas) 
sebagai Analogi Representasi Kebersamaan dalam Masyarakat Bugis. Narada, 5(2), 77-98. https://publikasi.mercubuana. ac.id/index.php/narada/article/view/2918

Mustapa, L. (2017). Pembaruan Pendidikan Islam: Studi atas Teologi Sosial Pemikiran KH Ahmad Dahlan. Jurnal Ilmiah AL-Jauhari: Jurnal Studi Islam Dan Interdisipliner, 2(1), 90111. https://journal.iaingorontalo.ac.id/index.php/aj/article/ view/674

Mustika, D., \& Dastina, W. (2020). Religious, Economic, and Political Shifting in Inheritance System of Suku Anak Dalam. Abkam: Jurnal Ilmu Syariah, 20(1).

Nabi, N. (2013). Islamic Economic Thought in the Medieval. Journal of Islamic Thought and Civilization, 3(2), 21-33.

Najamuddin, N. (2015). Persaingan Elit Bangsawan dengan Kelompok Terdidik pada Masa Revolusi di Sulawesi Selatan. Istoria: Jurnal Pendidikan Dan Sejarah, 11(1). https://journal. uny.ac.id/index.php/istoria/article/view/5756

Nashir, H. (2018). Taawun Untuk Negeri. http://m.muhammadiyah. or.id/muhfile/file/PIDATO MILAD MUH 106.pdf

Nasir, B. M., Baharuddin, A. S., \& Zain, N. M. (2019). The Role of Islamic Movements in Enhancing Da'wah Work: The Malaysian Experience. Kemanusiaan: The Asian Journal of Humanities, 26.

Oktafia, R., \& Mawardi, I. (2017). Islamic Values In The Tradition of Samnn Community In East Java. Qudus International Journal of Islamic Studies, 5(1), 97-114.

Prasetyo, Y. E., Sumarti, T., Prasodjo, N. W., \& Abbas, A. (2013). Potret Pertukaran Sosial Di Pedesaan: Studi Kasus Terhadap Gantangan Di Tiga Desa Miskin Di Kabupaten Subang. Seminar Nasional \& Workshop: Peningkatan Inovasi Dalam Menanggulangi Kemiskinan-LIPI.

Purba, I. A., \& Ponirin, P. (2013). Perkembangan Amal Usaha Organisasi Muhammadiyah di Bidang Pendidikan dan Kesehatan. JPPUMA Jurnal Ilmu Pemerintahan Dan Sosial 
Politik Universitas Medan Area, 1(2), 101-111. http://ojs.uma. ac.id/index.php/jppuma/article/view/558/398

Qodir, Z. (2004). Syariah Demokratik: Pemberlakuan Syariah Islam di Indonesia. Yogyakarta: Pustaka Pelajar.

Saat, S. (2014). Guru: Status Dan Kedudukannya Di Sekolah Dan Dalam Masyarakat. Auladuna: Jurnal Pendidikan Dasar Islam, 1(1), 102-113. http://journal.uin-alauddin.ac.id/index. $\mathrm{php} /$ auladuna/article/view/545

Salman, D. (2012). Sosiologi Desa: Revolusi Senyap Dan Tarian Kompleksitas. Makassar: Ininnawa.

Sirait, S. (2016). Religious Attitudes of Theological Tradisionalist in the Modern Muslim Community: Study on Tahlilan in Kotagede. Journal of Indonesian Islam, 10(2), 237-260.

Soetomo. (2018). Masalah Sosial, Pembangunan Sosial Dan Kesejahteraan. Yogyakarta: Pustaka Pelajar.

Sugiyanto, E. K., Rahman, T., \& Santoso, A. (2020). Islamic Work Ethics in Building Work Life Balance to Achieve Islamic Job Satisfaction. Inferensi: Jurnal Penelitian Sosial Keagamaan, 14(2), 317-330. https://inferensi.iainsalatiga.ac.id/index.php/ inferensi/article/view/4406/pdf

Sumarno, S. (2017). Pembaharuan Pendidikan Islam di Indonesia (Studi Pemikiran KH Ahmad Dahlan). al-Murabbi: Jurnal Studi Kependidikan Dan Keislaman, 3(2), 227-251. http:// ejournal.kopertais4.or.id/mataraman/index.php/murabbi/ article/view/2603

Sumodiningrat, G., \& Wulandari, A. (2016). Membangun Indonesia Dari Desa. Yogyakarta: Media Pressindo.

Suryana, C. (2009). Kiprah Politik Dan Sejarah Organisasi Muhammadiyah di Indonesia. Ilmu Dakwah: Academic Journal for Homiletic Studies, 4(14), 625-638. https://journal. uinsgd.ac.id/index.php/idajhs/article/view/414/421

Suryanto, A. (2018). Pemberdayaan Zakat: Model Intervensi Kemiskinan Dengan Microfinance Syariah Berbasis Masyarakat 
DPU DT Jawa Barat, Indonesia. INFERENSI: Jurnal Penelitian Sosial Keagamaan, 12(1), 85-106.

Tjokrowinoto, M. (2012). Pembangunan: Dilema dan Tantangan. Yogyakarta: Pustaka Pelajar.

Walian, A. W. (2012). Konsepsi Islam Tentang Kerja Rekonstruksi Terhadap Pemahaman Kerja Seorang Muslim. An Nisa'a, 7(1), 65-80. http://jurnal.radenfatah.ac.id/index.php/annisa/article/ view/843

Widodo, H., \& Yusuf, M. (2019). Islam Berkemajuan Dalam Perspektif Muhammadiyah. Islamica: Jurnal Studi Keislaman, 13(2), 261-283. http://islamica.uinsby.ac.id/index.php/islamica/ article/view/474/549

Zubaedi. (2007). Wacana Pembangunan Alternatif: Ragam Perspektif Pengembangan Dan Pemberdayaan Masyarakat. Yogyakarta: Ar-Ruzz Media. 